\title{
The Impact of Corruption on Domestic and Foreign Investment in Indonesia
}

\author{
Devi Oktiani \\ Center for Research and Standardization of Industry Bandar Lampung \\ Ministry of Industry \\ Bandar Lampung, Indonesia \\ divya_de_vi@yahoo.com
}

\begin{abstract}
Corruption in Indonesia is a recognized problem which reduces the investment benefit and government effectiveness. The corruption level is indicated as Corruption Perception Index (CPI). The statistical analysis measure the correlation between CPI and domestic direct investment (DDI) and the correlation between CPI and foreign direct investment (FDI). This analysis describe the trend of annual CPI, domestic direct investment, and foreign direct investment in Indonesia. The findings indicate that the corruption level which represented as the CPI of Indonesia has impact on investment, especially the FDI.
\end{abstract}

Keywords-Corruption Perception Index (CPI); domestic direct investment (DDI); foreign direct investment (FDI); Indonesia; statistical analysis

\section{INTRODUCTION}

The definition of corruption according to the World Bank is the abuse of power to obtain private benefits and includes payments of bribes, embellishment, favoritisms, inappropriate use of influences, irregular payments in public contracting [1].Corruption is one of the issues related to government, law, religion, and politics. The level of corruption in countries level can be represented and measured as Corruption Perceptions Index (CPI) which measured by Transparency International. CPI measures the degree to which corruption is perceived to exist among public officials and politicians. The annual CPI scores of the countries vary from 100 which means very clean to 0 which means highly corrupt. The high numbers indicate less perception of corruption, whereas lower numbers indicate higher perception of corruption. The measure for perception is a combination of various studies that evaluate how business people and the public in general view the level of corruption within a country. The countries are ranked based on their scores.

Indonesia is the largest economy in Southeast Asia based on the nominal GDP. The business environment in Indonesia may has impact nationally, regionally and internationally. Indonesia has been an outlier within the Southeast Asia region, with lower inflows of foreign direct investment (FDI) compare to other countries, especially in manufacturing sector, and with lower inflows than could be expected from its size and other country characteristics[2]. A relatively poor business environment with inefficient institutions is an important cause of the low inflows of FDI in Indonesia. Poor institutions and corruption in Indonesia increase the costs of production [2]. The objective of this study is to analyze how the corruption in Indonesia influence the domestic direct investment (DDI) and FDI. The previous studies mentioned that corruption has significant impact on FDI in the host country. Most of the previous studies are analyze the impact of corruption on FDI, while only a few analyze about the impact of corruption on domestic investment. This paper compares the impact of corruption on domestic and foreign investment.

\section{A. CPI as a Country Level Corruption Measurement}

CPI is used by previous studies as a country's corruption level measurement. The CPI is used for measure the country's corruption level and how it impacts on FDI. The home country corruption which measured by CPI negatively impacts the overall FDI outflows, while the investors from countries with high levels of corruption do not seem to be deterred by a high level of corruption in the host country [1]. The study of the impact of corruption on FDI and tax revenue uses CPI as corruption indicator measurement shows that a one point improvementin CPI would generate on average additional FDI of $0.5 \%$ of GDP [3]. The previous study uses the CPIdata collected for the period 1999-2004 for all countries in the world indicates that on average the increase of CPI by one unit leads to an increase of the annual GDPper capita growth rate by $1.7 \%$ [4]. Mo[5] uses CPI for measure the corruption level for the period 1980 to 1985 . Robertson and Watson[6] find that corruption is one of the country-level influences on market entry, investment, and other decisions fundamental to strategic management at the international level, they use the CPI scores computed by Transparency International.

\section{B. Previous Study about the Impact of Corruption on FDI}

Azam and Ahmad [7] study the effect of corruption on FDI in a set of 33 less developed countries over the period 1985 to 2011, the result indicates that there is a negative correlation between corruption and FDI inflows. As an example of the study on a specific country, there is a significant relationship between the level of corruption and the inflow of FDI into 
Nigeria within the period of 1990-2010 [8]. Alemu [9]studies the effect of corruption on FDI inflow from 1995 to 2009 in 16 Asian economies, the empirical result indicates that a 1 percent increase in corruption level causes an approximately 9.1 percentage decrease in FDI inflow. Hossain [10]determines the relationship between FDI and corruption used panel data from 1998 to 2014 among 48 different countries, the result indicates that $1 \%$ decrease in the level of corruption may leads to about $8.15,9.25$ and $11.5 \%$ increase in FDI inflows. Habib and Zurawicki[11]study the impact of corruption on FDI. The results indicate that foreign investors generally avoid corruption because it is wrong and it can create operational inefficiencies.

The linear regression method has been used by previous studies. Procazka [12] evaluates the impact of corruption with special emphasis on inward FDI. The analysis on the 88 cross sectional data of 172 respective countries is done using regression analysis method. The results indicate that in case of only two variables, FDI and CPI, a simple regression model may be appropriate. The results of the regression prove that there are statistically significant relationship between FDI as the dependent variable and CPI as the independent variable. Mauro [13] finds that there is a negative and significant association between corruption and the investment rate, both in ordinary least square and in two secondary least square using the index of ethnolinguistic fractionalization as an instrument. Mo [5] studies the impact of corruption among 54 country, uses the ordinary least square and finds that a $1 \%$ increase in the corruption level reduces the growth rate by about $0.72 \%$ or a one-unit increase in the corruption index reduces the growth rate by $0.545 \%$. The corruption level is measured as the CPI for the period 1980 to 1985 . Quazi[14]analyzes the impact of corruption on FDI inflows in East Asia and South Asia - two regions that have recently received huge FDI inflows. Using least square methodology with 1995-2011 panel data, this study finds that the impact of corruption on FDI is significantly negative and robust. Al-Sadiq [15] reexamine the effects of corruption on FDI inflows by an econometric method based on panel data from 117 host countries over the period 1984-2004. The results show that the corruption level in the host country has an adverse effect on FDI inflows. A one-point increase in the corruption level leads to a reduction in per capita FDI inflows by about 11 percent, however, after controlling for other characteristics of the host country such as the quality of institutions, the negative effects of corruption disappear and sometimes it becomes positive but statistically insignificant.

The different impact of corruption on foreign versus local investor has been considered as an important distinction. Corruption has stronger impact on FDI relative to domestic investment in the host country [16],[17].

Some previous studies use multiple variables on analyze the impact of corruption on FDI. Gokmenogluand Alaghemand [18]consider the corruption risk as one of the fifteen variables determine the FDI. Javorcik and Wei [19]use multiple variables and mention that the empirical evidence shows that corruption reduces inward FDI and shifts the ownership structure towards joint ventures.

O'toole and Tarp [20]study about bribery and how it's impact on different size of the firms. They find that bribery has a negative and statistically significant effect on investment efficiency. The findings indicate that the effect is big for domestic small and medium enterprises, while for large firms, which include state and semi-state enterprises, as well as foreign-owned companies, bribery does not appear to have an effect on the efficiency of investment. The findings indicate that the investment efficiency of large firms, including state firms, and foreign-owned firms is not affected by bribery. One explanation for this is that large domestic firms are potentially in a position to use influence to bypass specific corrupt officials, which may facilitate a reduction in the bribe payments per unit sales.

There isa different impact of corruption between the less developed countries and the developed countries. TheFDI is indeed associated with higher levels of corruption in less developed countries, but not in developed countries. FDI has positive (increasing corruption) or negative effects (reducing corruption) on corruption depends on the host country's economic environment [21].

There is also a study which mentioned that there is no significant impact of corruption on FDI. Ravi [22] conducted a comparative study of the effect of corruption on FDI in China and India. Corruption in India has negatively affected FDI, whereas that is not true in China. The study finds that while corruption affects FDI inflows into a country, the effect also depends on nature of corruption and not only on size of corruption.

\section{METHODS}

The corruption level is measured as CPI. The annual CPI data are collected as the secondary data which published by Transparency International [23]. The annual data of domestic investment and FDI are collected as secondary which published by Statistics Indonesia [24],[25],[26]. The annual data of DDI and FDI are approved by Indonesian government from the Investment Coordinating Board (BKPM). Investment data exclude the investment in petroleum production, insurance, and banking sectors. The changes in investment status and those was taken off have been taken into account.

The impact of corruption on DDI and the impact of corruption on FDI are analyzed individually by simple linear regression method using SPSS software. The validity of the model and the significant level of variable are tested on $95 \%$ significant level, using $\mathrm{F}$ test and two tail t-test.

\section{A. Model 1: The impact of the CPI score on DDI}

This model simulates the correlation between CPI and DDI in the same year. CPI score in year $t$ indicated as $\mathrm{CPI}_{t}$. The null and alternative hypothesis are: 
- $\mathrm{H}_{0}$ : There is no significant impact of $\mathrm{CPI}_{\mathrm{t}}$ on DDI .

- $\mathrm{H}_{1}$ : There is a positive and a significant impact $\mathrm{CPI}_{t}$ on $\mathrm{DDI}_{\mathrm{t}}$.

\section{B. Model2: The impact of the previous year CPI score on $D D I$}

As the previous year CPI may has impact on the following year investment, the impact of the previous year corruption $\left(\mathrm{CPI}_{\mathrm{t}-1}\right)$ on the following year domestic investment will be tested with the following hypothesis:

- $\mathrm{H}_{0}$ : There is no significant impact of $\mathrm{CPI}_{\mathrm{t}-1}$ on DDI $\mathrm{D}_{\mathrm{t}}$.

- $\mathrm{H}_{1}$ : There is a positive and a significant impact $\mathrm{CPI}_{\mathrm{t}-1}$ on $\mathrm{DDI}_{\mathrm{t}}$.

\section{Model 3: The impact of the CPI score on FDI}

This model simulates the correlation between CPI and FDI in the same year. CPI score indicated as $\mathrm{CPI}_{t}$. The null and alternative hypothesis are:

- $\mathrm{H} 0$ : There is no significant impact of $\mathrm{CPI}_{\mathrm{t}}$ on $\mathrm{FDI}_{\mathrm{t}}$.

- H1: There is a positive and a significant impact $\mathrm{CPI}_{t}$ on $\mathrm{FDI}_{t}$.

\section{Model 4: The impact of the previous year CPI score on FDI}

This model analyzed the correlation between the previous year CPI and the following year FDI. The null and alternative hypothesis are:

- H0: There is no significant impact of $\mathrm{CPI}_{\mathrm{t}-1}$ on $\mathrm{FDI}_{\mathrm{t}}$.

- $\mathrm{H} 1$ : There is a positive and a significant impact $\mathrm{CPI}_{\mathrm{t}-1}$ on $\mathrm{FDI}_{\mathrm{t}}$.

\section{RESULTS AND DISCUSSION}

\section{A. The Annual CPI, DDI, and FDI of Indonesia}

Corruption in Indonesia affect every sector and level of the government, from the top executive, legislative and judicial branches down to regional and local officials. Corruption reduces government efficiency. Corruption is a potential threat to all sectors and institutions within a country.Corruption may has impact in every aspect of society, which means it has impact on the living standard. The impacts is not only on the economic values but also on trust among people. Investment may be affected by trust or distrust. The trust and distrust may have impact on investment location decision.

The success indicators of Indonesia on preventing corruption are the realization of transparent, accountable, and corruption free public services to minimize the chances of corruption which measured by CPI. Recent years the business environment is gradually better. The annual CPI of Indonesia increases slowly (Table 1), there is a sign of better condition while it is still far below the target. The corruption causes a relatively poor business environment and inefficient institutions. There are some provinces that in recent years have been able to implement good policies and improve local institutions. Indonesia is using these good examples for reform and change at a national level. The differences of corruption level among provinces may have impact on FDI inflows in each province. Previous study mention that there is an effect of corruption on the location decision of FDI by multinational enterprises [27].

Government of Indonesia made some regulation and law related to corruption preventive action, as the example is Presidential Decree no. 55 year 2012 about National Strategy of Prevention and Eradication Long Term (2012-2025) and Medium Term (2012-2014) [28].

The Corruption Eradication Commission (KPK), established in 2002 as an institution which was given mandate for prevention and investigation of corruption has brought high profile corruptor to the court. KPK was established because of the crisis of trust to the existing law enforcement agencies. Previous study mentions that since the KPK has taken up operations in 2004, CPI score of Indonesia has slowly increased and The Word Bank Institutes corruption control indicator has improved [29].

The efforts that have been made by the government of Indonesia does not instantly reduce corruption, improve the governance procedures and prevent social governance from corruption, collusion, and nepotism. Since the past five years, many corruption cases regarding state officials were processed in court. However, there are still many cases of corruption that have not even been resolved even though it has attracted the attention of a wide audience.

TABLE I. CPI OF INDONESIA

\begin{tabular}{|l|l|l|}
\hline Year & World Rank & CPI Score \\
\hline 2003 & 122 & 19 \\
2004 & 133 & 20 \\
2005 & 137 & 22 \\
2006 & 130 & 24 \\
2007 & 143 & 23 \\
2008 & 126 & 26 \\
2009 & 110 & 28 \\
2010 & 100 & 28 \\
2011 & 100 & 30 \\
2012 & 118 & 32 \\
2013 & 114 & 32 \\
2014 & 107 & 34 \\
2015 & 88 & 36 \\
\hline
\end{tabular}

The DDI and FDI realization tend to increase every year. The increasing of investment is a sign of good economic condition. Most of DDI and FDI are from the manufacturing sector. However, Lipsey[2] mentioned that the FDI in manufacturing sector in Indonesia is low compare to other South East Asia countries.In Indonesia, FDI is considered as an important factors in the process of economic development, as a desirable source of long-term finance and for the skill and technology transfer often associated with it. 
Investment is one component of Gross Domestic Product (GDP). GDP is used for measure the total production of a country in one year. As GDP equivalent to the size of market, it can be considered that the larger the size of the market, the larger the size of investment. GDP has positive relation with investment. The impact of corruption on investment may also has impact on GDP.

TABLE 2. DDI AND FDI REALIZATION IN INDONESIA

\begin{tabular}{|c|r|r|}
\hline Year & \multicolumn{1}{|c|}{ DDI } & \multicolumn{1}{c|}{ FDI } \\
& (Rp. 1.000.000.000) & (1000.000 US\$) \\
\hline 2010 & 60626.3 & 16214.8 \\
2011 & 76000.7 & 19474.5 \\
2012 & 92182.0 & 24564.7 \\
2013 & 128150.6 & 28617.5 \\
2014 & 156126.3 & 28529.7 \\
\hline
\end{tabular}

Data source: Statistics Indonesia [24], [25], [26]

\section{B. The Impact of $C P I_{t}$ on $D D I_{t}$}

The simple regression analysis of the impact of CPI on DDI indicates that on 95 significant level the null hypothesis cannot be rejected, because the probability $(0.11)$ is bigger than 0.05. Corruption has no significant impact on DDI within a year.

TABle 3. MOdel Summary AND ANOVA of THE TEST ON THE IMPACT OF CPIT ON DDIT

\begin{tabular}{|c|c|c|c|}
\hline Dependent Variable & R Square & Value-F & Significant Level \\
\hline DDI $_{t}$ & 0.627 & 5.045 & 0.11 \\
\hline
\end{tabular}

TABLE 4. REGRESSION RESULT OF INDEPENDENT VARIABLE OF THE TEST ON THE IMPACT OF CPI $_{\mathrm{T}}$ ON DDI

\begin{tabular}{|l|l|l|l|}
\hline $\begin{array}{c}\text { Independent } \\
\text { Variable }\end{array}$ & \multicolumn{1}{|c|}{ Coefficient } & \multicolumn{1}{|c|}{ Value-t } & \multicolumn{1}{c|}{$\begin{array}{c}\text { Significant } \\
\text { Level }\end{array}$} \\
\hline Constant & -429636.850 & -1.811 & 0.168 \\
$\mathrm{CPI}_{\mathrm{t}}$ & 17280.975 & 2.246 & 0.110 \\
\hline
\end{tabular}

\section{The Impact $C P I_{t-1}$ on $D D I_{t}$}

The simple regression analysis of the impact of previous year corruption perception index, $\mathrm{CPI}_{\mathrm{t}-1}$ on $\mathrm{DDI}_{\mathrm{t}}$ on $95 \%$ significant level indicates that the null hypothesis can be rejected, the F value probability $(0.015)$ is less than 0.05 . The $\mathrm{t}$-value probability $(0.015)$ is less than 0.025 . The model is valid and $\mathrm{CPI}_{\mathrm{t}-1}$ has a positive and a significant influence the DDI (Table 4). The increasing of 1 point of CPI score will increase the next year DDI Rp. 18,456,238,000,000. This amount is almost similar to $8 \%$ of a year DDI realization on 2014.

TABle 5. MOdEL SUMMARY AND ANOVA OF THE TEST ON THE IMPACT OF $\mathrm{CPI}_{\mathrm{T}} \mathrm{ON} \mathrm{DDI}_{\mathrm{T}}$

\begin{tabular}{|l|l|l|l|}
\hline Dependent Variable & R Square & Value-F & Significant Level \\
\hline DDI $_{t}$ & 0.894 & 25.325 & 0.015 \\
\hline
\end{tabular}

TABLE 6. REgRESSION RESUlt OF INDEPENDENT VARIABLE OF THE TEST ON THE IMPACT OF CPI $\mathrm{T}-1_{\text {ON DDI }}$

\begin{tabular}{|l|c|l|l|}
\hline \multicolumn{1}{|c|}{$\begin{array}{c}\text { Independent } \\
\text { Variable }\end{array}$} & Coefficient & Value-t & \multicolumn{1}{c|}{$\begin{array}{c}\text { Significant } \\
\text { Level }\end{array}$} \\
\hline Constant & -451069.945 & -4.092 & 0.026 \\
$\mathrm{CPI}_{\mathrm{t}-1}$ & 18456.238 & 5.032 & 0.015 \\
\hline
\end{tabular}

\section{The Impact of $\mathrm{CPI}_{t}$ on $\mathrm{FDI}_{t}$}

The simple regression analysis of the impact of perception index or $\mathrm{CPI}_{t}$ on FDI on $95 \%$ significant level indicates that the null hypothesis can be rejected, the $\mathrm{F}$ value probability $(0.015)$ is less than 0.05 . The $t-$ value probability $(0.018)$ is less than 0.025. The model is valid for predicting FDI. CPIt has a positively and significantly influence the FDI. The increasing of 1 point CPI score will increase the FDI $2,896,347,000$ US\$ within a year. The increasing of FDI is about $10 \%$ of the annual FDI inflow.

TABLE 7. MODEl SUMmaRy AND ANOVA OF THE TEST ON THE IMPACT OF $\mathrm{CPI}_{\mathrm{T}} \mathrm{ON} \mathrm{FDI}_{\mathrm{T}}$

\begin{tabular}{|l|l|l|l|}
\hline Dependent Variable & R Square & Value-F & Significant Level \\
\hline FDI $_{t}$ & 0.894 & 25.325 & 0.015 \\
\hline
\end{tabular}

TABLE 8. REGRESSION RESULT OF INDEPENDENT VARIABLE OF THE TEST ON THE IMPACT OF $\mathrm{CPI}_{\mathrm{T}} \mathrm{ON} \mathrm{FDI}_{\mathrm{T}}$

\begin{tabular}{|l|c|l|l|}
\hline $\begin{array}{c}\text { Independent } \\
\text { Variable }\end{array}$ & Coefficient & Value-t & \multicolumn{1}{c|}{$\begin{array}{c}\text { Significant } \\
\text { Level }\end{array}$} \\
\hline Constant & -65727.244 & -3.466 & 0.040 \\
$\mathrm{CPI}_{\mathrm{t}}$ & 2896.347 & 4.710 & 0.018 \\
\hline
\end{tabular}

\section{E. The Impact of $C P I_{t-1}$ on $F D I_{t}$}

The analysis of the impact of the previous year corruption perception index $\left(\mathrm{CPI}_{\mathrm{t}-1}\right)$ on $\mathrm{FDI}_{t}$ indicates that $\mathrm{CPI}_{\mathrm{t}-1}$ is

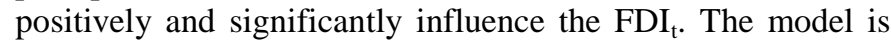
valid and the null hypothesis can be rejected, as the probability of $F$ value (0.006) is less than 0.05 , and the probability of $t-$ value 0.006 is less than 0.025 . The increasing of 1 point CPI score will increase the following year FDI 2,682,238,000 US\$. The increasing of FDI is about $10 \%$ of the annual FDI inflow.

TABLE 9. MODEl SUMmARY AND ANOVA OF THE TEST ON THE IMPACT OF $\mathrm{CPI}_{\mathrm{T}-1}$ ON FDI

\begin{tabular}{|l|l|l|l|}
\hline Dependent Variable & R Square & Value-F & Significant Level \\
\hline FDI $_{\mathrm{t}}$ & 0.994 & 50.883 & 0.006 \\
\hline
\end{tabular}

TABLE 10. REGRESSION RESULT OF INDEPENDENT VARIABLE OF THE TEST ON THE IMPACT OF $\mathrm{CPI}_{\mathrm{T}-1} \mathrm{ON} \mathrm{FDI}_{\mathrm{T}}$

\begin{tabular}{|l|c|l|l|}
\hline $\begin{array}{c}\text { Independent } \\
\text { Variable }\end{array}$ & Coefficient & Value-t & $\begin{array}{c}\text { Significant } \\
\text { Level }\end{array}$ \\
\hline Constant & -56986.885 & -5.043 & 0.015 \\
$\mathrm{CPI}_{\mathrm{t}-1}$ & 2682.238 & 7.133 & 0.006 \\
\hline
\end{tabular}




\section{CONCLUSION}

The findings indicate that the corruption level which represented as the CPI of Indonesia has impact on investment, especially the FDI. The previous year CPI score and the same year CPI score have positive and significant impact on the FDI realization. The previous year CPI score has positive and significant impact on DDI realization. However, the finding fails to reject the null hypothesis about the impact of the CPI score on the same year DDI realization. It is important for Indonesian government to ensure the better business environment, to reduce corruption and toimprove the international corruption perception of Indonesia.

\section{REFERENCES}

[1] Ferreira, M.P., Carreira, H.C., Li,D,, and Serra, F.R. "How corruption matters on FDI flows: home and host country effects," XXXVII Encontro de ANPAD. pp 1-16. Rio de Janeiro, September 2013.

[2] Lipsey, R.E. and Sjoholm, F. "FDI and growth in East Asia : lessons for Indonesia,” IFN Working Paper no.85, pp 1-48, Sweden, 2010.

[3] Ketkar, K.W., Murtuza, A., and Ketkar, S.L. " Impact of corruption on foreign direct investment and tax revenues," J. of Public Budgeting, Accounting, \& Financial Management, vol. 17(3), 2005, pp. 313-341.

[4] Podobnik, B., Shao, J., Njavro,D., Ivanov, P.C., and Stanley, H.E., “ Influence of corruption on economic growth rate and foreign investment," Eur. Phys. J.B., vol. 63, 2008, pp. 547-550.

[5] Mo, P.H., " Corruption and economic growth," Journal of Comparative Economics, vol.20, 2001, pp. 66-79.

[6] Robertson, C.J. and Watson, A., " Corruption and change: the impact of foreign direct investment," Strategic Management Journal, vol. 25, 2004 pp. 385-396.

[7] Azam, M. and Ahmad, S.A., " The effects of corruption on foreign direct investment inflows: some empirical evidence from less developed countries,” J. Appl. Sci. Res., vol. 9(6), 2013, pp. 3462-3467.

[8] Akinlabi, A.D., Hamed, B., and Awoniyi, M.A, " Corruption, foreign direct investment, and economic growth in Nigeria: an empirical investigation,” J. Res. Int. Bus. Manag., vol 1(9), 2011, pp. 278-292.

[9] Alemu, A.M., "Effects of corruption on FDI inflow in Asian economies," Seoul Journal of Economics, Vol. 25(4), 2012, pp 387-412.

[10] Hossain, S. "Foreign direct investment (FDI) and corruption: is it a major hiindrance for encouraging inward FDI?," Afr. J. Bus. Manage., vol 10(10), 2016, pp. 256-269.

[11] Habib, M. and Zurawicki, L., "Corruption and foreign direct investment," Journal of International Business Studies, vol. 33(2), 2002, pp. 291-307.
[12] Procazka, P., Maitah, M., and Pachmann, A., " Corruption and it influence on economy with focus on inflow of foreign direct investment," Modern Applied Science, vol. 9 (12), 2015, pp. 213-219.

[13] Mauro,P., "Corruption and growth," The Quarterly Journal of Economics, vol. 110(3), August 1995, pp. 681-712.

[14] Quazi, R.M., " Corruption and foreign direct investment in east asia and south asia: an econometric study," International Journal of Economics and Financial Issues, vol.4(2),April 2014, pp. 231-242.

[15] Al-Sadiq,A. "The effects of corruption on FDI inflows," Cato J., vol 29(2), 2009, pp. 267-294.

[16] Habib, M. and Zurawicki, L., "Country-level investments and the effect of corruption : some empirical evidence," International Bussiness Review, vol. 10, 2001, pp. 687-700.

[17] Zuwaricki, L. and Habib, M., " Corruption and foreign direct investment: what have we learned?, " International Business \& Economic Research Journal, vol. 9 (7), July 2010, pp. 1-10.

[18] Gokmenoglu, K.K. and Alaghemand, S., " A multi-critria decisionmaking model for evaluating priorities for Foreign Direct Investment,' CRORR, vol 6, 2015, pp. 489-510.

[19] Javorcik, B. S., and Wei, S.J., "Corruption and cross-border investment in emerging markets: firm-level evidence," Journal of International Money and Finance, vol.28, 2009, pp. 605-624.

[20] O'toole, C. and Tarp, F., "Corruption and the efficiency of capita investment in developing countries,” J.Int.Dev., vol. 26, March 2014 pp. 567-597.

[21] Pinto, P.M. and Zhu,B. "Fortune or evil? The effect of inward foreign direct investment on corruption," International Studies Quarterly, September 2016, pp. 1-13.

[22] Ravi, S.P., "Does corruption in a country affect the foreign direct investment? A study of rising economics super powers China and India," Open Journal of Social Science, vol.3, July 2015, pp. 99-104.

[23] Transparency International, "Corruption Preceptions Index 2015”, 2015, www.transparency.org

[24] BPS-Statistics Indonesia, Statistical Yearbook of Indonesia 2013 , Jakarta: BPS- Statistics Indonesia, 2013

[25] BPS-Statistics Indonesia, Statistical Yearbook of Indonesia 2014, Jakarta: BPS- Statistics Indonesia, 2014

[26] BPS-Statistics Indonesia, Statistical Yearbook of Indonesia 2014, Jakarta: BPS- Statistics Indonesia, 2015.

[27] Mudambi,R, Navarra, P, and Delios, A, "Government regulation, corruption, and FDI”, Asia Pac. J. Manag, vol. 30, 2013, pp. 458 - 511.

[28] Government of Indonesia, "Presidential Decree no. 55 year 2012 National Strategy of Prevention and Eradication Long Term (20122025) and Medium Term (2012-2014)"

[29] Schutte, S.A. "Against the odds: Anti-corruption reform in Indonesia", Public Admin. Dev, vol.32, 2012, pp. 38 - 48 . 